\title{
Lanostane Triterpenes from Gloeophyllum odoratum and Their Anti-Influenza Effects
}

Authors

Ulrike Grienke ${ }^{1}$, Julia Zwirchmayr ${ }^{1}$, Ursula Peintner ${ }^{2}$, Ernst Urban ${ }^{3}$, Martin Zehl ${ }^{4}$, Michaela Schmidtke ${ }^{5}$, Judith M. Rollinger ${ }^{1}$

Affiliations

1 Department of Pharmacognosy, Faculty of Life Sciences, University of Vienna, Austria

2 Institute of Microbiology, University of Innsbruck, Austria

3 Department of Pharmaceutical Chemistry, Faculty of Life Sciences, University of Vienna, Austria

4 Department of Analytical Chemistry, Faculty of Chemistry, University of Vienna, Austria

5 Institute of Medical Microbiology, Section Experimental Virology, Jena University Hospital, Germany

Key words

Gloeophyllum odoratum, Gloeophyllales, polypores, lanostane triterpenes, anti-influenza

received July 5, 2018

revised August 8, 2018

accepted August 14, 2018

Bibliography

DOI https://doi.org/10.1055/a-0690-9236

Published online August 21, 2018 | Planta Med 2019; 85:

195-202 @ Georg Thieme Verlag KG Stuttgart · New York | ISSN 0032-0943

Correspondence

Univ.-Ass. Mag. pharm. Dr. Ulrike Grienke

Department of Pharmacognosy, Faculty of Life Sciences,

University of Vienna

Althanstraße 14, 1090 Vienna, Austria

Phone: + 431427755262 , Fax: + 4314277855262

ulrike.grienke@univie.ac.at
$\Theta$ Supporting information available online at

http://www.thieme-connect.de/products

\begin{abstract}
In an in vitro screening for anti-influenza agents from European polypores, the fruit body extract of Gloeophyllum odoratum dose-dependently inhibited the cytopathic effect of the H3N2 influenza virus $\mathrm{A} /$ Hong Kong/68 $(\mathrm{HK} / 68)$ in Madin Darby canine kidney cells with a $50 \%$ inhibitory concentration (IC 50$)$ of $15 \mu \mathrm{g} / \mathrm{mL}$, a noncytotoxic concentration. After a chromatographic work-up, eight lanostane triterpenes (1-8) were isolated and their structures were elucidated based on high-resolution electrospray ionization mass spectrometry analyses, and one- and two-dimensional nuclear magnetic resonance experiments. Constituents 1 (gloeophyllin K) and 2 (gloeophyllin L) are reported here for the first time, and compounds 5, 7, and 8 have not been described for the investigated fungal material so far. The highest activity was determined for trametenolic acid B (3) against HK/68 and the 2009 pandemic $\mathrm{H} 1 \mathrm{~N} 1$ strain $\mathrm{A} /$ Jena/8178/09 with $\mathrm{IC}_{50}$ values of 14 and $11 \mu \mathrm{M}$, respectively. In a plaque reduction assay, this compound was able to bind to cell-free viruses and to neutralize their infectivity.
\end{abstract}

\section{Introduction}

Polypores, also known as conks, shelf fungi, or bracket fungi, are a morphologically distinct but polyphyletic group of Agaricomycetes (Basidiomycota) [1,2]. They are mostly growing on tree trunks, where they feed on wood by exuding enzymes to break down cellulose or lignin, thus causing wood rot. In central European folk medicines, polypore species (e.g., Laetiporus sulphureus, Fomes fomentarius, Fomitopsis pinicola, Piptoporus betulinus, and Laricifomes officinalis) have been widely used for the treatment of various diseases [3].
Gloeophyllum odoratum (Wulfen) Imazeki (syn. Osmoporus odoratus [Wulf. ex Fr.] or Trametes odorata [Wulf. ex Fr.]) is a bracket fungus from the order Gloeophyllales. This perennial wood-rotting fungus grows mainly on stumps of spruce and pine trees in Central Europe, Asia, and North America [4]. Due to its pleasant odor similar to anise or fennel it is commonly called "anise mazegill" [5].

Fruit bodies of $G$. odoratum have been mycochemically investigated concerning their volatile constituents (i.e., aliphatic alcohols, ketones, aldehydes, and monoterpenes) and nonvolatile constituents (i.e., aromatic compounds and tetracyclic lano- 


$\begin{array}{ll}\text { ABBREVIATIONS } \\ \text { CC }_{50} \quad 50 \% \text { cytotoxic concentration } \\ \text { CPE } & \text { cytopathic effect } \\ \text { ELSD } & \text { evaporative light scattering detector } \\ \text { FTIR } & \text { fourier-transform infrared spectroscopy } \\ \text { HK/68 } & \text { influenza virus A/Hong Kong/68 (H3N2) } \\ \text { HSQC } & \text { heteronuclear single quantum coherence } \\ \text { IAV } & \text { influenza A virus } \\ \text { MDCK } & \text { Madin Darby canine kidney } \\ \text { PDA } & \text { photo diode array } \\ \text { SFC } & \text { supercritical fluid chromatography } \\ \text { SI } & \text { selectivity index }\end{array}$

stane-type triterpenes) [4-12]. Regarding bioactivity on the extract level, immunomodulatory activity and cytotoxicity have been tested in vitro [13]. On the compound level, bioassay-guided fractionation led to the discovery of three $G$. odoratum lanostanes as thrombin inhibitors [9]. To date, no studies are available investigating the anti-influenza or any kind of antiviral properties of this species. However, lanostane triterpenes isolated from other polypores (e.g., Ganoderma sp. [Polyporales]) are reported to have an activity against IAV [14-16].

The limited portfolio of currently available and efficient agents against influenza prompted us to investigate the fruit body extracts of ten European polypore species in the search for highly needed novel anti-influenza scaffolds. In this study, we report on the isolation, structure elucidation, and the in vitro anti-influenza properties of two so far unknown triterpenes named gloeophyllin $K(1)$ and gloeophyllin L (2) and six known triterpenes (3-8) from the EtOH fruit body extract of $G$. odoratum.

\section{Results and Discussion}

To identify anti-influenza natural leads from polypores, EtOH extracts of fruit bodies of 10 species (i.e., F. fomentarius, F. pinicola, Ganoderma lucidum, Ganoderma applanatum, G. odoratum, Ischnoderma benzoinum, L. sulphureus, Phellinus robustus, P. betulinus, and Trametes gibbosa) were screened in a CPE inhibition assay with the H3N2 HK/68 in MDCK cells [17]. The EtOH fruit body extract of $G$. odoratum strain 0054 (GO54E) was identified as pronounced inhibitor of the CPE with an $\mathrm{IC}_{50}$ of $15 \mu \mathrm{g} / \mathrm{mL}$ [17]. Moreover, this extract was not cytotoxic to MDCK cells (measured up to $100 \mu \mathrm{g} /$ $\mathrm{mL})$.

GO54E (31.2 g) was suspended in water and partitioned sequentially between petroleum ether (GO54EP), dichloromethane (GO54ED), and water (GO54EW). By using TLC analysis, GO54ED was found to be enriched with lanostane triterpenes. This fraction was then subjected to several chromatographic steps including size exclusion, SFC, and silica flash chromatography, resulting in the isolation of eight triterpenes (1-8), namely $(24 E)-(3 \beta, 15 \alpha)$ 15-acetyloxy-3,26-dihydroxy-lanosta-8,24-dien-21-oic acid, referred to as gloeophyllin $\mathrm{K}(1),(3 S, 4 S, 4 \mathrm{a} R, 6 \mathrm{~b} R, 9 R, 10 \mathrm{a} R, 11 \mathrm{bS})-3-$ hydroxy-4,11b-dimethyl-10-methylene-9-((R)-6-methylhept-5en-2-yl)-2,3,4,4a,5,6,6b,7,8,9,10,10a,11,11b-tetradecahydro-
1H-benzo[a]fluorine-4-carboxylic acid, referred to as gloeophyllin L (2), trametenolic acid B (3), gloeophyllin B (4), gloeophyllin A (5), ergosterol peroxide (6), eburicodiol (7), and 21-hydroxylanosterol (8) ( $\triangleright$ Fig. 1).

The constituents were identified by means of HRESIMS and 1D and 2D NMR, and comparison of their spectroscopic data with published values. Constituents 1 and 2 are new triterpenes never described in the literature so far. The isolates 3, 4, and 6 have been reported previously from the fruit body of $G$. odoratum. The constituents 5, 7, and 8 are known natural compounds but new for this species.

The full assignments of the ${ }^{13} \mathrm{C}$ and ${ }^{1} \mathrm{H}$ NMR spectroscopic data of isolated new compounds 1 and 2 are listed in $>$ Table 1 . Their key HMBC, ${ }^{1} \mathrm{H}-{ }^{1} \mathrm{H}$ COSY, and NOESY correlations are presented in - Fig. 2. The respective NMR and HRESIMS spectra are provided in the Supporting Information.

Compound 1 was isolated as white, amorphous powder with the molecular formula $\mathrm{C}_{32} \mathrm{H}_{50} \mathrm{O}_{6}$, obtained by HRESIMS from the $\left[\mathrm{M}-\mathrm{H}_{2} \mathrm{O}+\mathrm{H}\right]^{+}$ion at $\mathrm{m} / \mathrm{z} 513.3575$ (calcd for $\mathrm{C}_{32} \mathrm{H}_{49} \mathrm{O}_{5}{ }^{+}$, 513.3575, $\Delta=-0.1 \mathrm{ppm}$ ) and the $[\mathrm{M}+\mathrm{Na}]^{+}$ion at $\mathrm{m} / \mathrm{z} 553.3499$ (calcd for $\mathrm{C}_{32} \mathrm{H}_{50} \mathrm{NaO}_{6}{ }^{+}$, 553.3500, $\Delta=0.1 \mathrm{ppm}$ ). The ${ }^{1} \mathrm{H}$ NMR spectrum exhibits resonances of seven methyl singlets at $\delta_{\mathrm{H}}$ $0.80,0.87,0.98,1.00,1.03,1.62$, and $2.03 .{ }^{13} \mathrm{C}$ NMR and APT spectra show resonances for one carboxylic acid carbon $\left(\delta_{C}\right.$ 180.5, C-21), one ester carbon $\left(\delta_{C} 172.9\right)$, two oxygenated methines $\left(\delta_{C} 79.5, C-3 ; \delta_{C} 77.2, C-15\right)$, and seven methyl moieties $\left(\delta_{C} 16.7,19.5,13.6,28.6,16.0,18.7,21.2\right)$. The HSQC spectrum was used to classify the remaining carbons as four methines, ten methylenes, and eight quaternary carbons. For the determination of the orientation of the acetoxy residue in position $\mathrm{C}-15$, the Karplus equation describing the relationship between the dihedral angle and the vicinal coupling constant ${ }^{3} \mathrm{~J}$ was used. Dihedral angles for both possible orientations of the acetoxy residue were calculated using Chem3D. The values obtained for $\alpha$ orientation clearly correspond to the experimentally obtained coupling constants in the ${ }^{1} \mathrm{H}$ NMR spectrum. Moreover, the interpretation of the NOE correlations allowed for the determination of the relative stereochemistry of compound 1 . In particular, the correlation between $\mathrm{H}-19 / \mathrm{H}-29$ proved the $\beta$ orientation of both methyl groups. Moreover, the correlation between $\mathrm{H}-3 / \mathrm{H}-28$ (both are $\alpha$ oriented) proved the $\beta$ orientation of the hydroxyl group in $\mathrm{C}-3$. The relative configurations at $\mathrm{C}-15, \mathrm{C}-17$ and $\mathrm{C}-20$ were determined by the NOEs of $\mathrm{H}-15 / \mathrm{H}-16$ a (both are $\beta$ ) and $\mathrm{H}-15 / \mathrm{H}-18$ (both are $\beta$ ), $\mathrm{H}-17 / \mathrm{H}-30$ (both are $\alpha$ ) and $\mathrm{H}-18 / \mathrm{H}-20(\mathrm{C}-20$ is $R$ ) and $\mathrm{H}-16 \mathrm{a} /$ $\mathrm{H}-22$ (C-20 is $R$ ). The assignment of $\mathrm{H}-16 \mathrm{a}$ and $\mathrm{H}-16 \mathrm{~b}$ was evaluated by the interpretation of the correlations between $\mathrm{H}-18 / \mathrm{H}$ $16 \mathrm{~b}(\mathrm{H}-16 \mathrm{~b}$ is $\alpha$ oriented) and $\mathrm{H}-15 / \mathrm{H}-16 \mathrm{a}(\mathrm{H}-16 \mathrm{a}$ is $\beta$ oriented). The stereochemistry of the double bond between C-24/C-25 was deduced from the correlations between $\mathrm{H}-24 / \mathrm{H}-26(E)$ and $\mathrm{H}-23 /$ $\mathrm{H}-27(E)$.

Based on these data, the new natural compound 1 was identi-

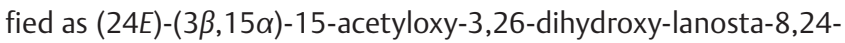
dien-21-oic acid and named gloeophyllin K.

Constituent 2, having a molecular formula of $\mathrm{C}_{29} \mathrm{H}_{44} \mathrm{O}_{3}(\mathrm{~m} / \mathrm{z}$ $439.3225[\mathrm{M}-\mathrm{H}]^{-}$; calcd for $\mathrm{C}_{29} \mathrm{H}_{43} \mathrm{O}_{3}{ }^{-}, 439.3218, \Delta=-1.6 \mathrm{ppm}$ and $\mathrm{m} / \mathrm{z} 463.3183[\mathrm{M}+\mathrm{Na}]^{+}$; calcd for $\mathrm{C}_{29} \mathrm{H}_{44} \mathrm{O}_{3} \mathrm{Na}^{+}, 463.3183$, $\Delta=-0.2 \mathrm{ppm})$, was also obtained as a white, amorphous powder. 

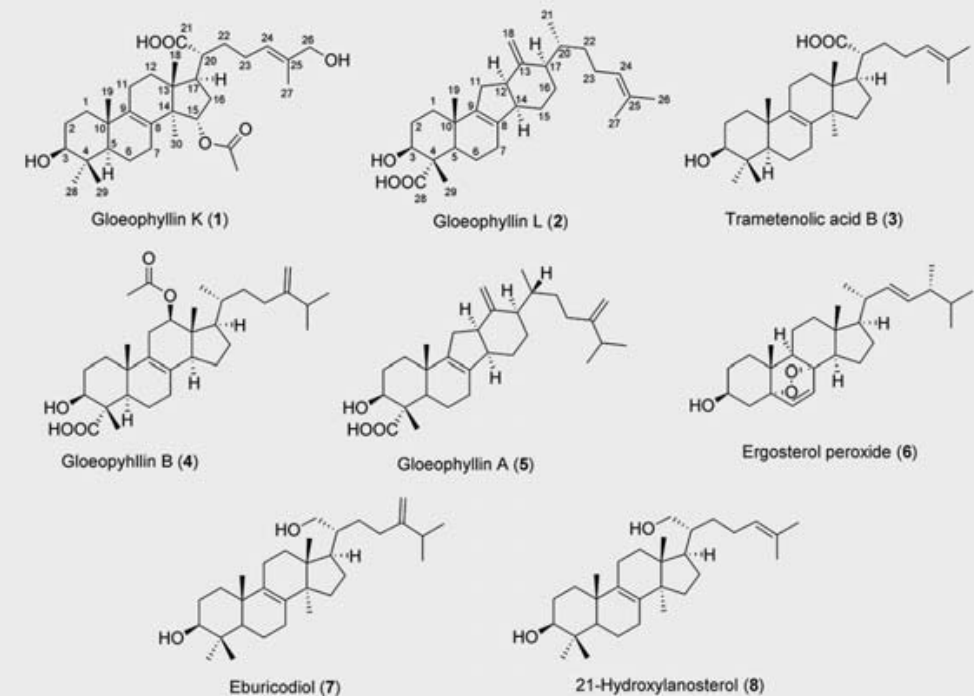

- Fig. 1 Chemical structures of isolated and identified G. odoratum triterpenes.

The ${ }^{1} \mathrm{H}$ NMR spectrum exhibits resonances of one secondary methyl at $\delta_{H} 0.89(\mathrm{~d}, J=6.7 \mathrm{~Hz})$, singlets of four tertiary methyl groups at $\delta_{\mathrm{H}} 0.98,1.12,1.61$, and 1.66 and two vinyl proton signals at $\delta_{\mathrm{H}} 4.66$ and $\delta_{\mathrm{H}} 4.82(\mathrm{H}-18 \mathrm{a} / \mathrm{b})$. Additionally, the ${ }^{13} \mathrm{C} \mathrm{NMR}$ and APT spectra of 2 show one oxygenated methine at $\delta_{C} 76.5$ (C-3) and one carboxylic moiety at $\delta_{C} 181.7$ (C-28) in its structure. As reported for gloeophyllin A (5) [18], the interpretation of the ${ }^{1} \mathrm{H}-{ }^{1} \mathrm{H}$ COSY and the HMBC data confirmed the presence of a rare 6/6/5/6 ring system, a so called C-nor-D-homoergosteroid skeleton.

The configurations of the methyl group at C-29 and the hydroxyl group in $\mathrm{C}-3$ were found to be $\beta$ oriented by NOEs of $\mathrm{H}$ $19 / \mathrm{H}-29$ and $\mathrm{H}-3 / \mathrm{H}-5$, respectively. The configurations at $\mathrm{C}-12$, $\mathrm{C}-14$, and $\mathrm{C}-17$ were assigned via NOE correlations between $\mathrm{H}$ $12 / \mathrm{H}-14$ and $\mathrm{H}-12 / \mathrm{H}-17$, proving an $\alpha$ orientation of $\mathrm{H}-12, \mathrm{H}-14$, and $\mathrm{H}-17$. Thus, the structure of the new compound 2 can be assigned to $(3 S, 4 S, 4 \mathrm{a} R, 6 \mathrm{~b} R, 9 R, 10 \mathrm{a} R, 11 \mathrm{bS})$-3-hydroxy-4,11b-dimethyl-10-methylene-9-((R)-6-methylhept-5-en-2-yl)-2,3,4,4a,5, 6,6b,7,8,9,10,10a,11,11b-tetradecahydro-1H-benzo[a]fluorine4-carboxylic acid (atom numbering according to systematic name generation), for which we gave the trivial name gloeophyllin L.

Triterpenes with this rare and unusual backbone have only been reported once from a fungal source (i.e., Gloeophyllum abietinum grown in Tibet) [18]. Biosynthetically, it is assumed that C-nor-D-homoergosteroids arise via a Wagner-Meerwein rearrangement reaction from a classical lanostane triterpene precursor. Here, the cleavage of carbon bonds between C-13/C-14 and C-8/C-14 are key steps.

The six known lanostane triterpenoids were identified by comparing their spectroscopic and spectrometric data (1D and 2D NMR and HRESIMS) with those in the literature: trametenolic acid B (3) [19], gloeophyllin B (4) [18], gloeophyllin A (5) [18], ergosterol peroxide (6) [20], eburicodiol (7) [21], and 21-hydroxylanosterol (8) [22]. Copies of the original spectra for known compounds are obtainable from the corresponding author.
All G. odoratum isolates were tested in an in vitro CPE inhibition assay using the IAV H3N2 strain HK/68 and the 2009 pandemic H1N1 strain A/Jena/8178/09 (Jena/8178; • Table 2). Additionally, their cytotoxicity was evaluated in MDCK cells. The SI of each compound was calculated $\left(\mathrm{CC}_{50} / \mathrm{IC}_{50}\right)$ to evaluate the specificity of antiviral activity. The higher the SI, the lower is the risk of false-positive results.

Compounds 1,2 , and 4-6 showed no or weak anti-influenza virus activities, whereby compounds 2 and 4-6 exerted strong cytotoxicity with $\mathrm{CC}_{50}$ values between 7.3 and $45 \mu \mathrm{M}$. Whereas compounds 7 and 8 could only moderately protect MDCK cells against HK/68 infection, they significantly reduced the CPE caused by Jena/8178 to $50 \%$ at low micro molar concentrations (15.4 $\mu \mathrm{M}$ and $9.0 \mu \mathrm{M}$, respectively).

Compound 3 was identified as novel anti-influenza virus agent against both $\mathrm{HK} / 68$ and Jena/8178. Its $\mathrm{IC}_{50}$ values are in the low micro molar range with 14.1 and $11.3 \mu \mathrm{M}$, respectively.

Based on the available data, it seems that an $\mathrm{OH}$ group in the form of an alcohol (compounds 7 and 8) or carboxylic acid (compounds 1 and 3) at position C-21 is favorable for the observed anti-influenza activity. However, more conclusive structure activity relationships between the features of the investigated triterpenes and the observed antiviral effects could not be established. Regarding the anti-influenza mechanism of action of the most effective compound 3 , results from a fluorescence-based neuraminidase inhibition assay showed that this target protein on the viral surface can be excluded (data not shown). To evaluate the effects of compound 3 on the cell-free virus and different stages of the viral replication cycle, a modified plaque-reduction assay was performed. Here, 3 was able to bind to cell-free viruses and to neutralize their infectivity ( $\vee$ Fig. 3 ). Virus neutralization can be based on inhibitor binding to the viral envelope glycoproteins (i.e., hemagglutinin or neuraminidase, which are crucial for viral attachment and release, respectively) [23-25]. Hence, our data give first hints about possible targets of compound 3, which warrants 
- Table $1{ }^{1} \mathrm{H}$ and ${ }^{13} \mathrm{C}$ NMR spectroscopic data of 1 and $2\left({ }^{1} \mathrm{H}: 500 \mathrm{MHz}, \mathrm{CD}_{3} \mathrm{OD}, \delta\right.$ in ppm, $J$ in $\mathrm{Hz} ;{ }^{13} \mathrm{C}: 125 \mathrm{MHz}, \mathrm{CD}_{3} \mathrm{OD}, \delta$ in ppm, multiplicities determined by APT experiments).

\begin{tabular}{|c|c|c|c|c|}
\hline \multirow[t]{2}{*}{ Position } & \multicolumn{2}{|l|}{1} & \multicolumn{2}{|l|}{2} \\
\hline & $\delta_{\mathrm{H}}$ & $\delta_{\mathrm{C}}$ & $\delta_{\mathrm{H}}$ & $\delta_{c}$ \\
\hline 1 & $\begin{array}{l}1.75, \mathrm{~m} \\
1.22, \mathrm{~m}\end{array}$ & 33.9, $\mathrm{CH}_{2}$ & $\begin{array}{l}1.70, \mathrm{~m} \\
1.37, \mathrm{~m}\end{array}$ & $36.8, \mathrm{CH}_{2}$ \\
\hline 2 & $1.63, \mathrm{~m}$ & $28.4, \mathrm{CH}_{2}$ & $\begin{array}{l}1.70, \mathrm{~m} \\
1.68, \mathrm{~m}\end{array}$ & $28.1, \mathrm{CH}_{2}$ \\
\hline 3 & $3.15, \mathrm{dd}(9.1,7.0)$ & $79.5, \mathrm{CH}$ & $4.01, \mathrm{dd}(10.8,5.1)$ & $76.5, \mathrm{CH}$ \\
\hline 4 & - & $39.9, \mathrm{C}$ & - & 54.7, C \\
\hline 5 & $1.03, \mathrm{~m}$ & $51.7, \mathrm{CH}$ & 1.87, dd $(12.4,1.5)$ & $48.6, \mathrm{CH}$ \\
\hline 6 & $\begin{array}{l}2.07, \mathrm{~m} \\
2.02, \mathrm{~m}\end{array}$ & 21.7, $\mathrm{CH}_{2}$ & $\begin{array}{l}1.66, \mathrm{~m} \\
1.37, \mathrm{~m}\end{array}$ & $22.5, \mathrm{CH}_{2}$ \\
\hline 7 & $\begin{array}{l}2.10, \mathrm{~m} \\
1.89, \mathrm{~m}\end{array}$ & 27.7, $\mathrm{CH}_{2}$ & $\begin{array}{l}2.05, \mathrm{~m} \\
1.91, \mathrm{~m}\end{array}$ & 25.7, $\mathrm{CH}_{2}$ \\
\hline 8 & - & $134.0, \mathrm{C}$ & - & $138.0, \mathrm{C}$ \\
\hline 9 & - & $137.1, \mathrm{C}$ & - & 143.9, C \\
\hline 10 & - & $38.3, \mathrm{C}$ & - & $36.1, C$ \\
\hline 11 & $\begin{array}{l}1.71, \mathrm{~m} \\
1.54, \mathrm{~m}\end{array}$ & $19.3, \mathrm{CH}_{2}$ & $2.27, d(9.2)$ & $36.2, \mathrm{CH}_{2}$ \\
\hline 12 & $\begin{array}{l}1.81, \mathrm{~m} \\
1.48, \mathrm{~m}\end{array}$ & $30.2, \mathrm{CH}_{2}$ & $2.86, \mathrm{dt}(9.2,9.2,8.5)$ & $46.6, \mathrm{CH}$ \\
\hline 13 & - & $45.8, \mathrm{C}$ & - & 152.7, C \\
\hline 14 & - & 51.9, C & $2.36, \mathrm{dt}(8.5,7.5,7.5)$ & 49.6, CH \\
\hline 15 & $5.03, \mathrm{dd}(9.6,5.6)$ & $77.2, \mathrm{CH}$ & $\begin{array}{l}1.54, \mathrm{~m} \\
1.16, \mathrm{~m}\end{array}$ & 24.8, $\mathrm{CH}_{2}$ \\
\hline 16 & $\begin{array}{l}2.08, \mathrm{~m} \\
1.72, \mathrm{~m}\end{array}$ & $36.4, \mathrm{CH}_{2}$ & $\begin{array}{l}1.68, \mathrm{~m} \\
1.45, \mathrm{~m}\end{array}$ & 27.3, $\mathrm{CH}_{2}$ \\
\hline 17 & 2.22 , overlapped & $47.2, \mathrm{CH}$ & $1.94, \mathrm{~m}$ & $50.2, \mathrm{CH}$ \\
\hline 18 & $0.87, \mathrm{~s}$ & $16.8, \mathrm{CH}_{3}$ & $\begin{array}{l}4.82, \mathrm{~d}(2.4) \\
4.66, \mathrm{~d}(2.4)\end{array}$ & $112.4, \mathrm{CH}_{2}$ \\
\hline 19 & $1.01, \mathrm{~s}$ & $19.5, \mathrm{CH}_{3}$ & $0.98, \mathrm{~s}$ & $20.4, \mathrm{CH}_{3}$ \\
\hline 20 & 2.22 , overlapped & $49.2, \mathrm{CH}$ & $1.60, \mathrm{~m}$ & $33.9, \mathrm{CH}$ \\
\hline 21 & - & $180.5, C$ & $0.89, \mathrm{~d}(6.7)$ & $18.9, \mathrm{CH}_{3}$ \\
\hline 22 & $1.51, \mathrm{~m}$ & $33.4, \mathrm{CH}_{2}$ & $\begin{array}{l}1.59, \mathrm{~m} \\
1.00, \mathrm{~m}\end{array}$ & $35.3, \mathrm{CH}_{2}$ \\
\hline 23 & $2.03, \mathrm{~m}$ & 26.5, $\mathrm{CH}_{2}$ & $\begin{array}{l}2.05, \mathrm{~m} \\
1.96, \mathrm{~m}\end{array}$ & $26.2, \mathrm{CH}_{2}$ \\
\hline 24 & $5.38, \mathrm{dt}(7.2,7.2,1.1)$ & $125.8, \mathrm{CH}$ & $5.08, \mathrm{~m}$ & 125.9, CH \\
\hline 25 & - & 136.7, C & - & $132.1, \mathrm{C}$ \\
\hline 26 & $3.91, \mathrm{~s}$ & $68.9, \mathrm{CH}_{2}$ & $1.67, \mathrm{~s}$ & $26.0, \mathrm{CH}_{3}$ \\
\hline 27 & $1.62, \mathrm{~s}$ & 13.7, $\mathrm{CH}_{3}$ & $1.60, \mathrm{~s}$ & $17.8, \mathrm{CH}_{3}$ \\
\hline 28 & $0.98, \mathrm{~s}$ & 28.6, $\mathrm{CH}_{3}$ & - & 181.7, C \\
\hline 29 & $0.80, s$ & $16.2, \mathrm{CH}_{3}$ & $1.12, \mathrm{~s}$ & $11.5, \mathrm{CH}_{3}$ \\
\hline 30 & $1.04, \mathrm{~s}$ & 18.7, $\mathrm{CH}_{3}$ & - & - \\
\hline Ac $\underline{\mathrm{COO}}$ & - & 172.9, C & - & - \\
\hline $\mathrm{Ac} \underline{\mathrm{C}} \mathrm{H}_{3}$ & $2.03, \mathrm{~s}$ & $21.2, \mathrm{CH}_{3}$ & - & - \\
\hline
\end{tabular}


further investigation through more specific tests in a follow-up study.

In sum, $G$. odoratum fruit bodies have shown to be a rich source of anti-influenza triterpenes (3, 7, and 8). In particular, the most active ingredient-that is, trametenolic acid $B(3)$-is one of the major triterpenes contained in the EtOH extract ( 3\%).

\section{Materials and Methods}

\section{General experimental procedures}

Optical rotations were measured at $20^{\circ} \mathrm{C}$ in $\mathrm{MeOH}$ on a Perkin-Elmer 341 polarimeter. FTIR spectra were acquired on a Bruker Tensor 27 spectrometer. 1D and 2D NMR experiments were performed by using a Bruker Avance 500 NMR spectrometer (UltraShield) with a 5-mm switchable probe ( $\mathrm{TCl}$ Prodigy CryoProbe, $5 \mathrm{~mm}$, triple resonance inverse detection probe head) as described before [26]. The samples (1-2 mg) were measured at $298 \mathrm{~K}$ in fully deuterated $\mathrm{MeOH}$ referenced to the residual nondeuterated solvent signals. HRMS analyses were performed on a Bruker Daltonics maXis HD ESI-Qq-TOF mass spectrometer equipped with ESI in the positive and negative modes: capillary voltage, $1.5-4.5 \mathrm{kV}$; nebulizer, 0.4 bar $\left(\mathrm{N}_{2}\right)$; dry gas flow, $4 \mathrm{~L} / \mathrm{min}\left(\mathrm{N}_{2}\right)$; dry temperature, $200^{\circ} \mathrm{C}$. The sum formulas of the ions were determined using Bruker Compass DataAnalysis 4.2 based on the mass accuracy ( $\Delta$ $\mathrm{m} / \mathrm{z} \leq 2 \mathrm{ppm}$ ) and isotopic pattern matching (SmartFormula algorithm). Flash chromatography was performed on an Interchim puriFlash 4250 system, equipped with an ELSD and a PDA detector. Semi-preparative SFC was performed on a Waters Prep-15 System as described previously [27]. A Waters Viridis BEH column (5 $\mu \mathrm{m}$; $10 \times 250 \mathrm{~mm}$ ) served as stationary phase. The mobile phase consisted of a supercritical $\mathrm{CO}_{2} /$ organic modifier $(\mathrm{EtOH})$ gradient $(\mathrm{T}$, $40^{\circ} \mathrm{C}$; flow rate, $15 \mathrm{~mL} / \mathrm{min}$ ). The fractions obtained from all chromatographic steps were analyzed by TLC (mobile phase: dichloromethane-MeOH-water $[10: 1.0: 0.25])$; stationary phase: Merck silica gel $60 \mathrm{PF}_{254}$, detected after derivatization with vanillin/ $\mathrm{H}_{2} \mathrm{SO}_{4}(5 \%$ in $\mathrm{MeOH})$ under visible light, $\mathrm{UV}_{254}$, and UV 366 . HPLC analysis was performed on a Dionex Ultimate 3000 RS system, equipped with a PDA detector and a charged aerosol detector on an Agilent Zorbax SB-C 18 rapid-resolution column $(3.5 \mu \mathrm{m}$, $4.6 \times 150 \mathrm{~mm}$ ) with a MeCN/water gradient as mobile phase (0 min 45\%/55\%, $42 \min 80 \% / 20 \%, 43 \min 95 \% / 5 \%, 53 \min 95 \% /$ $5 \%, 54 \min 45 \% / 55 \%, 64 \min 45 \% / 55 \%)$. Conditions: $\mathrm{T}, 35^{\circ} \mathrm{C}$; flow rate, $1 \mathrm{~mL} / \mathrm{min}$; injection volume, $10 \mu \mathrm{L}$; detection wavelength, 210, $254 \mathrm{~nm}$. UPLC analysis was performed on a Waters Acquity UPLC system (H-class) equipped with a PDA detector and an ELSD. The stationary phase was a Waters Acquity UPLC BEH Phenyl column $(1.7 \mu \mathrm{m}, 2.1 \times 100 \mathrm{~mm})$. The mobile phase consisted of a MeCN/water gradient $(0 \mathrm{~min} 84 \% / 16 \%, 1.5 \mathrm{~min} 86 \% / 14 \%$, $1.6 \min 98 \% / 2 \%, 2.9 \min 98 \% / 2 \%, 3 \min 84 \% / 16 \%)$. Conditions: $\mathrm{T}, 40^{\circ} \mathrm{C}$; flow rate, $0.6 \mathrm{~mL} / \mathrm{min}$; injection volume, $5 \mu \mathrm{L}$; detection wavelength, $210 \mathrm{~nm}$, and full range scan 190-400 nm.

(Ultrahigh-)gradient grade solvents and deuterated solvents from Merck were used.

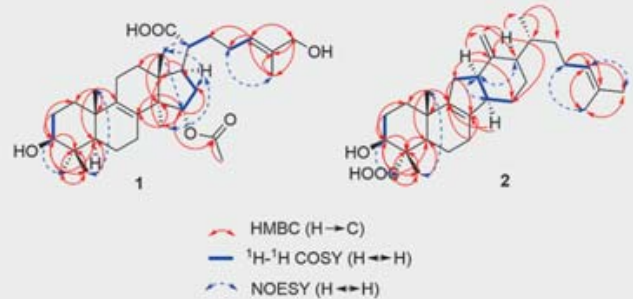

- Fig. 2 Key HMBC, ${ }^{1} \mathrm{H}^{-1} \mathrm{H}$ COSY, and NOESY correlations of compounds 1 and 2.

\section{Fungal material}

The fruit bodies of investigated polypores were collected in 2013 in Tyrol, Austria, and South Tyrol, Italy. They were dried at $40^{\circ} \mathrm{C}$ for $5 \mathrm{~d}$. Voucher specimens are deposited in the Herbarium of the Department of Pharmacognosy, University of Vienna, Austria. Exact collection locations/source and voucher ID numbers are the following: F. fomentarius: Neue Magdeburger Hütte (1300 m), Zirl, Austria (grown on beech), ID: FomfomE0019; F. pinicola: Viggartal, Ellbögen, Austria (grown on dead spruce trunk), ID: FompinE0010; G. lucidum: Plantasia GmbH, Oberndorf bei Salzburg, Austria, ID: 680898; G. applanatum: Oberperfuss, Austria (grown on spruce), ID: GanappE0012; G. odoratum: Oberperfuss, Austria (grown on spruce), ID: GloodoE0054, JR-20140310-A1; I. benzoinum: Geigerhof, Innichen/Vierschach in South Tyrol (Pustertal), Italy (grown on conifer wood), ID: IscbenE0038, L. sulphureus: Oberperfuss, Austria (grown on deciduous tree), ID: LaesulE0043; P. robustus: Hötting, Austria (grown on dead beech), ID: PherobE002; P. betulinus: Vill, Innsbruck, Austria (grown on birch); ID: PipbetE0029; T. gibbosa: Gnadenwald, Austria (grown on beech), ID: TragibE0052 [17]. Phylogenetic analyses were used to confirm the morphological identification and partial sequences of ITS rRNA were used to characterize the strains [28].

\section{Extraction and isolation}

The dried and powdered fruit bodies of $G$. odoratum strain 54 (389.0 g) were macerated at r. t. with EtOH 96\% ( $3 \times 5 \mathrm{~L}, 5$ d each). After removal of the solvent under vacuum, the EtOH extract $(31.2 \mathrm{~g})$ was suspended in water and partitioned sequentially between petroleum ether (GO54EP; $5.6 \mathrm{~g})$, dichloromethane (GO54ED; $18.4 \mathrm{~g})$, and water (GO54EW; $2.8 \mathrm{~g}$ ).

Of the G054ED fraction, $12.8 \mathrm{~g}$ were subjected to silica gel column chromatography (Merck silica gel $60 \mathrm{PF}_{254}, 517 \mathrm{~g} ; 55 \times 5 \mathrm{~cm}$ ) using a gradient system of dichloromethane-ethyl acetate-MeOH $(7.5 \mathrm{~L})$ to give 17 fractions (A1-A17). Fraction A10 (2958$3247 \mathrm{~mL}$ ) was recrystallized from acetone and identified as compound $3(980 \mathrm{mg})$. Fractions A14-A15 (4896-6154 mL, $1.2 \mathrm{~g})$ were combined and further separated via flash chromatography (PuriFlash $\mathrm{C}_{18}$ HQ column [15 $\mathrm{m}, 55 \mathrm{~g}$ ]; flow rate: $26 \mathrm{~mL} / \mathrm{min}$ ) applying a gradient system of MeCN/water as mobile phase (0 min $10 \% / 90 \%, 40 \min 95 \% / 5 \%, 70 \mathrm{~min} 95 \% / 5 \%$ ) to yield 10 fractions (B1-B10). Fraction B3 (574-602 mL, $48.0 \mathrm{mg}$ ) was purified via 
- Table 2 Cytotoxicity and anti-influenza virus activity of compounds 1-8. CC 50 in MDCK cells and IC ${ }_{50}$ determined against HK/68 and Jena/8178 in the CPE inhibition assay in MDCK cells are presented ( $n=3 ; n$. a.: not active).

\begin{tabular}{|c|c|c|c|c|c|}
\hline \multirow[t]{2}{*}{ Code } & \multirow{2}{*}{$\begin{array}{l}\mathrm{CC}_{50}(\mathrm{Cl} 195)[\mu \mathrm{M}] \text { in } \\
\text { MDCK cells }\end{array}$} & \multicolumn{2}{|c|}{$\mathrm{IC}_{50}(\mathrm{Cl} 95)[\mu \mathrm{M}]$ of CPE in MDCK cells } & \multirow{2}{*}{$\begin{array}{l}\text { SI IAV HK/68 } \\
{\left[\mathrm{CC}_{50} / \mathrm{IC}_{50}\right]}\end{array}$} & \multirow{2}{*}{$\begin{array}{l}\text { SI IAV Jena/8178 } \\
{\left[\mathrm{CC}_{50} / \mathrm{IC}_{50}\right]}\end{array}$} \\
\hline & & $\begin{array}{l}\text { IAV } \\
\text { HK/68 }\end{array}$ & $\begin{array}{l}\text { IAV } \\
\text { Jena/8178 }\end{array}$ & & \\
\hline Gloeophyllin K (1) & $>100$ & n.a. & $\begin{array}{l}46.4 \\
(40.14-54.45)\end{array}$ & - & $>2$ \\
\hline Gloeophyllin L (2) & $\begin{array}{l}45.5 \\
(37.35-54.26)\end{array}$ & n. a. & n.a. & - & - \\
\hline Trametenolic acid B (3) & $>100$ & $\begin{array}{l}14.1 \\
(9.76-19.16)\end{array}$ & $\begin{array}{l}11.3 \\
(9.74-14.41)\end{array}$ & $>7$ & $>9$ \\
\hline Gloeophyllin B (4) & $\begin{array}{l}35.5 \\
(27.88-43.94)\end{array}$ & n.a. & n.a. & - & - \\
\hline Gloeophyllin A (5) & $\begin{array}{l}17.8 \\
(15.81-19.81)\end{array}$ & n.a. & n.a. & - & - \\
\hline Ergosterol peroxide (6) & $\begin{array}{l}7.31 \\
(4.96-11.47)\end{array}$ & n.a. & n.a. & - & - \\
\hline Eburicodiol (7) & $>100$ & $\begin{array}{l}31.2 \\
(17.66-48.01)\end{array}$ & $\begin{array}{l}15.4 \\
(8.13-25.07)\end{array}$ & $>3$ & $>6$ \\
\hline 21-Hydroxylanosterol (8) & $>100$ & $\begin{array}{l}34.5 \\
(23.84-47.14)\end{array}$ & $\begin{array}{l}9.00 \\
(7.72-10.42)\end{array}$ & $>3$ & $>11$ \\
\hline Oseltamivir & - & $\begin{array}{l}0.004 \\
(0.0004-0.01)\end{array}$ & $\begin{array}{l}0.076 \\
(0.06-0.10)\end{array}$ & - & - \\
\hline
\end{tabular}

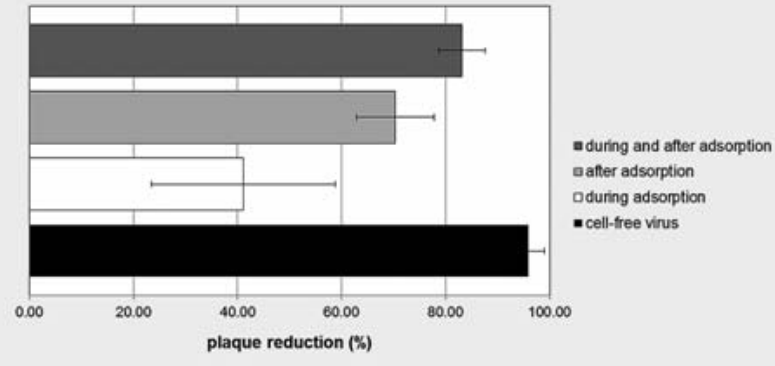

Fig. 3 Inhibition of different stages of the life cycle of IAV HK/68 by compound 3 at $100 \mu \mathrm{M}$ (plaque reduction assay performed in MDCK cells). Bars represent the mean values and SD of at least three experiments, each with two parallels per concentration.

another flash chromatography (PuriFlash $\mathrm{C}_{18} \mathrm{HQ}$ column [15 $\mu \mathrm{m}$, $35 \mathrm{~g}$; flow rate: $15 \mathrm{~mL} / \mathrm{min}$ ) applying a gradient system of MeCN/ water as mobile phase (0 min 35\%/65\%, 50 min 50\%/50\%, 52 min $95 \% / 5 \%, 55 \min 95 \% / 5 \%$ ) to yield three fractions (C1-C3). Fraction C3 (432-448 mL) was identified as compound 1 (16.2 mg).

Fraction A12 (1.3 g) was suspended in water and partitioned sequentially between $n$-hexane (D1), ethyl acetate (D2), and water (D3). Fraction D2 (1.1 g) was further separated via flash chromatography (PuriFlash $\mathrm{C}_{18}$ HQ column [15 $\mu \mathrm{m}, 55 \mathrm{~g}$ ]; flow rate: $26 \mathrm{~mL} / \mathrm{min}$ ) applying a gradient system of MeCN/water as mobile phase $(0 \min 45 \% / 55 \%$, 30 min $80 \% / 20 \%$, 55 min $98 \%$ / $2 \%, 65 \min 98 \% / 2 \%$ ) to yield nine fractions (E1-E9). Fraction E6
(1050-1155 mL, $130 \mathrm{mg}$ ) was subjected to semi-preparative SFC (Viridis BEH column [ $5 \mu \mathrm{m}, 10 \times 250 \mathrm{~mm}$ ]; flow rate: $15 \mathrm{~mL} / \mathrm{min}$ ) applying a gradient system of supercritical $\mathrm{CO}_{2} / \mathrm{EtOH}$ as mobile phase $(0 \mathrm{~min} 90 \% / 10 \%, 8 \mathrm{~min} 90 \% / 10 \%$, $9.5 \mathrm{~min} 50 \% / 50 \%$, $11.5 \min 50 \% / 50 \%, 12 \min 90 \% / 10 \%, 13 \min 90 \% / 10 \%)$ to yield three fractions (F1-F3). Fraction F2 was identified as compound $4(45.0 \mathrm{mg})$. Fraction E7 (1156-1215 mL, $34 \mathrm{mg})$ was subjected to semi-preparative SFC (Viridis BEH column [5 $\mu \mathrm{m}, 10 \times$ $250 \mathrm{~mm}$ ]; flow rate: $15 \mathrm{~mL} / \mathrm{min}$ ) applying a gradient system of supercritical $\mathrm{CO}_{2} / \mathrm{EtOH}$ as mobile phase $(0 \mathrm{~min} 92 \% / 8 \%$, $9.5 \mathrm{~min}$ $92 \% / 8 \%, 10 \min 50 \% / 50 \%, 11 \min 50 \% / 50 \%, 11.5 \min 92 \% / 8 \%$, $12 \min 92 \% / 8 \%$ ) to yield three fractions (G1-G3). Fraction G2 was identified as compound 2 (5.2 mg). Fraction E8 (1216$1395 \mathrm{~mL}, 63 \mathrm{mg}$ ) was subjected to semi-preparative SFC (Viridis BEH column [ $5 \mu \mathrm{m}, 10 \times 250 \mathrm{~mm}$ ]; flow rate: $15 \mathrm{~mL} / \mathrm{min}$ ) applying a gradient system of supercritical $\mathrm{CO}_{2} / \mathrm{EtOH}$ as mobile phase (0 min 92\%/8\%, $9.5 \min 92 \% / 8 \%, 10 \min 50 \% / 50 \%, 11 \min 50 \% /$ $50 \%, 11.5 \mathrm{~min} 92 \% / 8 \%, 12 \mathrm{~min} 92 \% / 8 \%$ ) to yield three fractions $(\mathrm{H} 1-\mathrm{H} 3)$. Fraction $\mathrm{H} 3$ was identified as compound 5 (16.7 mg).

Fraction A8 (2.6-2.8 L, $350 \mathrm{mg}$ ) was separated via flash chromatography (PuriFlash $\mathrm{C}_{18}$ HQ column [ $15 \mu \mathrm{m}, 35 \mathrm{~g}$ ]; flow rate: $15 \mathrm{~mL} / \mathrm{min}$ ) applying a gradient system of MeCN/water as mobile phase (0 min 45\%/55\%, 35 min 80\%/20\%, 60 min 98\%/2\%, 90 min $98 \% / 2 \%)$ to yield 19 fractions (I1-I19). Fraction 117 (1068$1176 \mathrm{~mL}$ ) was identified as compound 6 (11.9 mg).

The $\mathrm{MeOH}$ soluble part of fraction A9 $(2788-2941 \mathrm{~mL}$, $260.4 \mathrm{mg}$ ) was purified via Sephadex LH-20 column chromatography (mobile phase: $\mathrm{MeOH}$ ) yielding seven fractions (J1-J7). Fractions J2-J3 (66-114 mL, $191 \mathrm{mg}$ ) were combined and further separated via silica gel column chromatography (Merck silica gel 60 
$\mathrm{PF}_{254}, 110 \mathrm{~g} ; 95 \times 2 \mathrm{~cm}$ ) eluting with a gradient solvent system of dichloromethane-MeOH, yielding nine fractions (K1-K9). Fraction K2 (856-912 mL, $69.5 \mathrm{mg}$ ) was further separated via silica gel column chromatography (Merck silica gel $60 \mathrm{PF}_{254}, 14 \mathrm{~g} ; 40 \times 1 \mathrm{~cm}$ ) eluting with an isocratic solvent system of dichloromethane$\mathrm{MeOH}(10: 0.25)$ to yield eight fractions (L1-L8). Fraction L3 (48-60 mL, $35 \mathrm{mg}$ ) was purified via silica gel column chromatography (Merck silica gel $60 \mathrm{PF}_{254}, 11 \mathrm{~g} ; 26 \times 1 \mathrm{~cm}$ ) eluting with a gradient solvent system of dichloromethane- $\mathrm{MeOH}$, yielding 10 fractions (M1-M10). Fraction M4 (282-300 mL, $2.2 \mathrm{mg}$ ) was finally purified via UPLC including a fraction manager giving $1.0 \mathrm{mg}$ of compound 7 and $1.0 \mathrm{mg}$ of compound 8 .

The purity of the isolated compounds was determined by HPLC-PDA-MS to be $>98 \%$.

Gloeophyllin K (1): white, amorphous powder; $[\alpha]_{D}^{20}+43.6^{\circ}(c$ $0.10, \mathrm{MeOH}) ;{ }^{1} \mathrm{H}$ and ${ }^{13} \mathrm{C}$ NMR, see $>$ Table 1 ; HRESIMS $\mathrm{m} / \mathrm{z}$ $553.3499[\mathrm{M}+\mathrm{Na}]^{+}$(calcd for $\mathrm{C}_{32} \mathrm{H}_{50} \mathrm{NaO}_{6}{ }^{+}, 553.3500, \Delta=$ $0.1 \mathrm{ppm})$.

Gloeophyllin $L(2)$ : white, amorphous powder; $[\alpha]_{D}^{20}+21.9^{\circ}(c$ 0.33, MeOH); ${ }^{1} \mathrm{H}$ and ${ }^{13} \mathrm{C}$ NMR, see $>$ Table 1 ; HRESIMS $\mathrm{m} / \mathrm{z}$ $439.3225[\mathrm{M}-\mathrm{H}]^{-}$(calcd for $\mathrm{C}_{29} \mathrm{H}_{43} \mathrm{O}_{3}{ }^{-}, 439.3218, \quad \Delta=$ $-1.6 \mathrm{ppm})$.

\section{Cell culture and viruses}

Jena/8178 isolated from nasal swabs of an influenza patient during the pandemic of 2009 [29] and HK/68 (strain collection of the Institute of Medical Microbiology, Section Experimental Virology, Jena University Hospital Jena, Germany) were used in antiviral studies. They were propagated in MDCK cells (FriedrichLoeffler Institute, Riems, Germany) in serum-free Eagle's minimum essential medium, $2 \mu \mathrm{g} / \mathrm{mL}$ trypsin, and $1.2 \mathrm{mM}$ bicarbonate [30]. Titers of virus stocks were determined according to [31] in MDCK cells.

\section{Determination of cytotoxicity and CPE inhibition}

The $\mathrm{CC}_{50}$ as well as $\mathrm{IC}_{50}$ (inhibition of virus-induced $\mathrm{CPE}$ ) was determined on 2-d-old confluent MDCK cell monolayers grown in 96-well plates as described previously (maximum tested concentration: $100 \mu \mathrm{g} / \mathrm{mL}$ for extracts/fractions and $100 \mu \mathrm{M}$ for pure compounds) [32]. The $\mathrm{CC}_{50}$ value represents the inhibitor concentration that reduces the viability of the treated cells in comparison to untreated control cells (no inhibitor) by half. For the calculation of these values, the mean optical density of six crystal violet stained cell controls was set to $100 \%$ viability [32]. In the CPE inhibition assay, six wells of untreated, noninfected (100\% viability; no CPE) and six wells of untreated, infected cells (nearly complete CPE and no viability), without the test compound served as cell and virus control, respectively, on each plate. The percentage of antiviral activity of the tests compounds was calculated according to Pauwels et al. (1988) [33] using the following equation: antiviral activity $=[$ (mean optical density of 6 cell controls - mean optical density of 6 virus controls)/(optical density of test - mean optical density of 6 virus controls)] $\times 100 \%$. A $100 \%$ CPE inhibition means that $100 \%$ of virus-infected, inhibitor-treated cells were viable. The $I_{50}$ is the concentration of a virus inhibitor, where the response (CPE caused by the virus) is reduced by half (result- ing in $50 \%$ cell viability $=50 \%$ of the mean optical density of the six cell controls).

All compounds were solved in DMSO. The maximum applied solvent concentration was $0.5 \%(\mathrm{v} / \mathrm{v})$. Cytotoxicity was analyzed $72 \mathrm{~h}$ after adding the samples. CPE inhibition was measured $48 \mathrm{~h}$ after infection. A multiplicity of infection of 0.0008 and $0.003 \mathrm{TCID}_{50} /$ cell of Jena/8178 and $\mathrm{HK} / 68$, respectively, resulted in a complete CPE at this time point. Each concentration was tested twice. At least three experiments were performed. Data leading to the determination of $\mathrm{CC}_{50}$ and $\mathrm{IC}_{50}$ values are provided as dose-response curves in Fig. 24S, Supporting Information. $\mathrm{CC}_{50}$ and $\mathrm{IC}_{50}$ values were calculated from mean dose-response curves of at least three independent experiments. Linear regression analysis using Microsoft Excel was applied in the linear scaled dose-dependent sample concentrations. To evaluate the specificity of antiviral activity, the $\mathrm{SI}$ was calculated as $\mathrm{CC}_{50} / \mathrm{IC}_{50}$ ratio. Oseltamivir served as a positive control.

\section{Plaque reduction assay}

The assay time and temperature conditions of the plaque reduction assay were described recently $[25,34]$ and slightly modified. Here, confluent MDCK cell monolayers grown in 12-well plates were inoculated with $~ 30$ pfu HK/68 in 500- $\mu \mathrm{L}$ test medium. Cells and/or virus were exposed to $3(100 \mu \mathrm{M})$ before infection, during the viral adsorption phase, after adsorption phase, or during the whole replication cycle. Nontreated virus controls were included in all assays. Three independent assays were performed.

\section{Supporting Information}

The NMR, HRESIMS, and IR spectra of compounds 1 and 2 and graphs showing dose-dependencies for the investigated compounds (Fig. 24S) are provided as Supporting Information (Fig. 1S-23S).

\section{Acknowledgements}

The authors thank S. Pucher (Institute of Pharmacy/Pharmacognosy, University of Innsbruck, Austria), N. Lukovic and N. Prenner (Department of Pharmacognosy, University of Vienna, Austria), and B. Jahn (Institute of Medical Microbiology, Section Experimental Virology, Jena University Hospital, Germany) for technical assistance. This work was supported by the Austrian Science Fund (FWF: P24587) and the European Social Fund (ESF \& TMWAT Project 2011 FGR 0137).

\section{Conflict of Interest}

The authors declare no conflicts of interest.

\section{References}

[1] Binder M, Justo A, Riley R, Salamov A, Lopez-Giraldez F, Sjokvist E, Copeland A, Foster B, Sun H, Larsson E, Larsson KH, Townsend J, Grigoriev IV, Hibbett DS. Phylogenetic and phylogenomic overview of the Polyporales. Mycologia 2013; 105: 1350-1373

[2] Garcia-Sandoval R, Wang Z, Binder M, Hibbett DS. Molecular phylogenetics of the Gloeophyllales and relative ages of clades of Agaricomycotina producing a brown rot. Mycologia 2011; 103: 510-524 
[3] Grienke U, Zöll M, Peintner U, Rollinger JM. European medicinal polypores - a modern view on traditional uses. J Ethnopharmacol 2014; 154: $564-583$

[4] Kahlos K. The characterization of some lipid metabolites of Gloeophyllum odoratum grown in vitro. Mycol Res 1996; 100: 23-26

[5] Rösecke J, Pietsch M, König WA. Volatile constituents of wood-rotting basidiomycetes. Phytochemistry 2000; 54: 747-750

[6] Rösecke J, König WA. Odorous compounds from the fungus Gloeophyllum odoratum. Flavour Fragrance J 2000; 15: 315-319

[7] Rösecke J, König WA. Constituents of various wood-rotting basidiomycetes. Phytochemistry 2000; 54: 603-610

[8] Cateni F, Lucchini V, Zacchigna M, Procida G, Doljak B, Anderluh M. New triterpenes from the fungus Gloeophyllum odoratum. Chem Nat Compd 2015; 51: 74-80

[9] Cateni F, Lucchini V, Anderluh M, Martinuzzi P, Zacchigna M, Piltaver A, Doljak B. Triterpenes from Gloeophyllum odoratum as potential leads towards potent thrombin inhibitors. Lett Drug Des Discov 2010; 7: 521-527

[10] Kahlos K, Kiviranta JL], Hiltunen RVK. Volatile constituents of wild and in vitro cultivated Gloeophyllum odoratum. Phytochemistry 1994; 36: 917922

[11] Rasser F, Anke T, Sterner O. Secondary metabolites from a Gloeophyllum species. Phytochemistry 2000; 54: 511-516

[12] Halsall TG, Hodges R, Sayer GC. The chemistry of the triterpenes and related compounds. Part XXXVI. Some constituents of Trametes odorata (Wulf.) Fr. J Chem Soc 1959: 2036-2040

[13] Doskocil I, Havlik J, Verlotta R, Tauchen J, Vesela L, Macakova K, Opletal L, Kokoska L, Rada V. In vitro immunomodulatory activity, cytotoxicity and chemistry of some central European polypores. Pharm Biol 2016; 54 : 2369-2376

[14] Zhu Q, Bang TH, Ohnuki K, Sawai T, Sawai K, Shimizu K. Inhibition of neuraminidase by Ganoderma triterpenoids and implications for neuraminidase inhibitor design. Sci Rep 2015; 5: 13194

[15] Mothana RA, Awadh Ali NA, Jansen R, Wegner U, Mentel R, Lindequist U. Antiviral lanostanoid triterpenes from the fungus Ganoderma pfeifferi. Fitoterapia 2003; 74: 177-180

[16] Grienke U, Kaserer T, Pfluger F, Mair CE, Langer T, Schuster D, Rollinger JM. Accessing biological actions of Ganoderma secondary metabolites by in silico profiling. Phytochemistry 2015; 114: 114-124

[17] Grienke U, Mair CE, Kirchmair J, Schmidtke M, Rollinger JM. Discovery of bioactive natural products for the treatment of acute respiratory infections - an integrated approach. Planta Med 2018; 84: 684-695

[18] Han J], Bao L, Tao QQ, Yao Y], Liu XZ, Yin WB, Liu HW. Gloeophyllins A-J, cytotoxic ergosteroids with various skeletons from a Chinese Tibet fungus Gloeophyllum abietinum. Org Lett 2015; 17: 2538-2541

[19] Rösecke J, König WA. Steroids from the fungus Fomitopsis pinicola. Phytochemistry 1999; 52: 1621-1627

[20] Kobori M, Yoshida M, Ohnishi-Kameyama M, Takei T, Shinmoto H. 5alpha,8alpha-Epidioxy-22E-ergosta-6,9(11),22-trien-3beta-ol from an edible mushroom suppresses growth of HL60 leukemia and HT29 colon adenocarcinoma cells. Biol Pharm Bull 2006; 29: 755-759

[21] Kikuchi T, Uchiyama E, Ukiya M, Tabata K, Kimura Y, Suzuki T, Akihisa T. Cytotoxic and apoptosis-inducing activities of triterpene acids from Poria cocos. J Nat Prod 2011; 74: 137-144

[22] Su H], Fann YF, Chung MI, Won S], Lin CN. New lanostanoids of Ganoderma tsugae. J Nat Prod 2000; 63: 514-516

[23] Gilbertson B, Ng WC, Crawford S, McKimm-Breschkin JL, Brown LE. Mouse saliva inhibits transit of influenza virus to the lower respiratory tract by efficiently blocking influenza virus neuraminidase activity. J Virol 2017; 91: e00145-17

[24] Zeng LY, Yang J, Liu S. Investigational hemagglutinin-targeted influenza virus inhibitors. Expert Opin Investig Drugs 2017; 26: 63-73

[25] Hoffmann A, Richter M, von Grafenstein S, Walther E, Xu Z, Schumann L, Grienke U, Mair CE, Kramer C, Rollinger JM, Liedl KR, Schmidtke M, Kirchmair J. Discovery and characterization of diazenylaryl sulfonic acids as inhibitors of viral and bacterial neuraminidases. Frontiers Microbiol 2017; 8: 205

[26] Mair CE, Grienke U, Wilhelm A, Urban E, Zehl M, Schmidtke M, Rollinger JM. Anti-influenza triterpene saponins from the bark of Burkea africana. J Nat Prod 2018; 81: 515-523

[27] Scheuba J, Wronski VK, Rollinger JM, Grienke U. Fast and green - $\mathrm{CO}_{2}$ based extraction, isolation, and quantification of phenolic styrax constituents. Planta Med 2017; 83: 1068-1075

[28] Dresch P, MN DA, Rosam K, Grienke U, Rollinger JM, Peintner U. Funga strain matters: colony growth and bioactivity of the European medicinal polypores Fomes fomentarius, Fomitopsis pinicola and Piptoporus betulinus. AMB Express 2015; 5: 4

[29] Walther E, Xu Z, Richter M, Kirchmair J, Grienke U, Rollinger JM, Krumbholz A, Saluz HP, Pfister W, Sauerbrei A, Schmidtke M. Dual acting neuraminidase inhibitors open new opportunities to disrupt the lethal synergism between Streptococcus pneumoniae and influenza virus. Front Microbiol 2016; 7: 357

[30] Bauer K, Richter M, Wutzler P, Schmidtke M. Different neuraminidase inhibitor susceptibilities of human $\mathrm{H} 1 \mathrm{~N} 1, \mathrm{H} 1 \mathrm{~N} 2$, and H3N2 influenza A viruses isolated in Germany from 2001 to 2005/2006. Antiviral Res 2009; 82: 34-41

[31] Reed LJ, Muench H. A simple method of estimating fifty per cent endpoints. Am J Epidemiol 1938; 27: 493-497

[32] Schmidtke M, Schnittler U, Jahn B, Dahse H, Stelzner A. A rapid assay for evaluation of antiviral activity against coxsackie virus B3, influenza virus A, and herpes simplex virus type 1. J Virol Methods 2001; 95: 133-143

[33] Pauwels R, Balzarini J, Baba M, Snoeck R, Schols D, Herdewijn P, Desmyter J, De Clercq E. Rapid and automated tetrazolium-based colorimetric assay for the detection of anti-HIV compounds. J Virol Methods 1988; 20: 309-321

[34] Makarov VA, Braun H, Richter M, Riabova OB, Kirchmair J, Kazakova ES, Seidel N, Wutzler P, Schmidtke M. Pyrazolopyrimidines: potent inhibitors targeting the capsid of rhino- and enteroviruses. ChemMedChem 2015; 10: 1629-1634 